\title{
The Effectiveness of Anti-Corruption: A Comparative Study between the Ming Dynasty's Touring Censorial Inspectors and the Current Central Leading Group for Inspection Work
}

\author{
Lu Yang, Yan Wang, Sen Yang \\ School of Government, Beijing Normal University, Beijing, China \\ Email: bnu yangluu@163.com
}

Received 13 July 2016; accepted 2 August 2016; published 5 August 2016

Copyright (C) 2016 by authors and Scientific Research Publishing Inc.

This work is licensed under the Creative Commons Attribution International License (CC BY). http://creativecommons.org/licenses/by/4.0/

(c) (7) Open Access

\begin{abstract}
Since the 18th CPC National Congress, China has cracked down hard on corruption. Among all the efforts, the Central Leading Group for Inspection Work has made the most contribution. As some people consider the Ming Dynasty's Touring Censorial Inspectors as “China's Ancient Central Leading Group for Inspection Work", it is not difficult to find out certain similarity existing between these two kinds of anti-corruption mechanisms that have both made certain accomplishments. If boiled down to their nature, both the Central Leading Group for Inspection Work and the Touring Censorial Inspector System reflect the authorization-agency mechanism, which is plagued with asymmetric information and other problems. By comparing the Ming Dynasty's Touring Censorial Inspectors, i.e. a typical example of the ancient inspection system, and the Central Leading Group for Inspection Work-the main anti-corruption body since the 18th CPC National Congress, lessons from the ancient practices can be drawn for today's reference, which are both conducive to providing theoretical basis for advancing China's current anti-corruption tasks and promoting the anti-corruption effectiveness and offer suggestions to enhance anti-corruption progress in China.
\end{abstract}

\section{Keywords}

Ming Dynasty's Touring Censorial Inspectors, The Central Leading Group for Inspection Work, Effectiveness of Anti-Corruption, Comparative Study, Authorization-Agency Mechanism 


\section{Introduction}

Corruption, as a common problem in every country throughout the world, has been rapidly sprawling in China. Such phenomenon not only imperils and damages the authority and effectiveness of law, but also destroys China's socialist economic bases and shakes its social political basis, therefore forming a potential threat to our Party, nation and society as well. Under modern democracy and the rule of law, what corruption abuses is public power; what it impairs is public interests. As a result, it is required publicly to exterminate corruption for preservation of people's public interests, which reflects democracy-based political ethics. This is a fundamental symbol of the people as masters over China. If not fighting against corruption, the state power will not have the people’s support anymore [1]. "Anti-corruption and Clean Government Promotion” has thus been considered as part of political ethics as well as the key to two essential segments of political ethics, namely, governmental and official ethics.

As historian Wu Han said, "The Twenty-Four Histories (dynastic histories from remote antiquity till the Ming Dynasty) has been flooded with stories about corruption.” Nevertheless, the past 5000 years overflow with cases of corruption as well as fights against them. The inspection system played an important role in anti-corruption in ancient China, and the Ming Dynasty's Touring Censorial Inspector mechanism is a paragon with typical significance [2]. In their touring inspection, the Censorial Inspectors realized their anti-corruption function through inspecting documentary files, interrogating and recording criminal cases and checking various administrative affairs, which had exerted a tremendous influence on the gain or loss of the state order, benefit or malady of civil or military affair, as well as promoting the beneficial and abolishing the harmful. In addition, the mechanism itself had been most developed. The currently adopted in China is a two-level inspection system, i.e. inspection by both the central government as well as the governments at provincial level and in autonomous regions and municipalities directly under the central government, which turns out to be an institutional innovation for effectively containing power corruption. In particular, since the 18th CPC National Congress, the new administration has pushed forward the fight against corruption with all its strength, persisting in cracking down on both "tigers" and "flies" (namely, low-level and high-level corrupted officials). After several rounds of inspection by the Central Leading Group for Inspection Work, a large number of high-rank officials at vice-ministerial level and above have been removed from their office after the Central Leading Group for Inspection Work entered and stationed in their work areas and investigated the problems reported by the residents to work tirelessly to oppose four forms of undesirable work styles: formalism, bureaucratism, hedonism and extravagance, which has initially restrained the sprawling anti-corruption trend [3]. However, while the anti-corruption work has made breakthroughs, problems such as "promotion of officials with disciplinary offence and unlawful conducts", "loss of evidence when the related documents are being sent to the judicial organs" and even "rebound of corruption" are still existing. Besides, though Ming Dynasty's Touring Censorial Inspector system was almost perfect, it didn’t really pave the way for the Dynasty to maintain a lasting peace and order, on the contrary, it even quickened the collapse of the late Ming Dynasty. Therefore, the effectiveness of anti-corruption by both the Central Leading Group for Inspection Work and Ming's Touring Censorial Inspectors has to be examined and weighed.

It is not difficult to find when comparing the Central Leading Group for Inspection Work with the Ming Dynasty's Touring Censorial Inspectors that certain similarity exists between these two kinds of anti-corruption mechanisms and both have made some accomplishments. However, under different historical backgrounds what eventually arise from the two mechanisms is completely contrasting results. However, limitations from different historical backgrounds are not the focus of this study, which attempts to make comparisons in aspects of the anti-corruption mechanisms and their effectiveness between the Ming Dynasty's Touring Censorial Inspectors and the Central Leading Group for Inspection Work so as to find out the influencing factors for anti-corruption effectiveness and provide reference for the Central Leading Group for Inspection Work to better implement its work.

\section{Literature Review and Current Research}

Ancient China's specific inspection system, since its inception in Qin and Han, had been most developed up till Ming and Qing Dynasties after the development of more than 1500 years. The appointment of Censorial Inspectors was the best embodiment in this regard. In recent years, the Ming Dynasty's inspector system has become a new point in studying ancient inspection system at which scholars make breakthroughs. From historiography's point of view, Yu Xing'an analyzed in depth the formulation of the inspector system, the system's re- 
quirements for inspector' s touring, the scope of inspector duties, examination and promotion/dismissal of such inspector. In the end, Yu proposed that the system in question was initiated in early Ming when the empire enacted the Constitution Outline in the Fourth Year of Zhengtong Period; and specified inspector's touring duration, residence, attendants, finance, etiquette governing his meeting with local officials, etc. Moreover, it stipulated in detail inspector duties such as inspecting documentary files, interrogating and recording criminal cases and checking various administrative affairs [2]. And based on Yu's research, CaiMinglun further clarified the characteristics of this system [4]. Liang Erming, instead, according to his own focus, argued that inspector, thanks to his crucial and influential inspection, served as a bridge between the central regime and the local governing. Moreover, various forms of such inspection made it possible to effectively supervise all local civil and military officials in legislation, administration and suchlike [5]. In addition, the academic circle often critically reflected on impacts of the inspector. Ai Yongming et al., for example, held that the best-developed inspection system between Ming and Qing had its bright side as well as dark side. Indeed, it led to a serious and notorious malady that the inspectors who should act against corruption committed such hideous crime. These inspectors not only lived extravagantly and squandered public funds and materials, but even received or even asked bribes without the slightest concealment. In brief, the system in question had completely deviated from its primary intent [6].

The currently adopted two-level inspection system by the Central Government and provincial governments is an institutional innovation to improve the inner-party inspection system in the new era and is of great significance. In Particular, the Central Leading Group for Inspection Work has played the most significant role in its remarkable efficiency against corruption, therefore drawing wide attention from the scholars who put forward their own opinions regarding the efficiency and weakness of the Central Leading Group for Inspection Work's anti-corruption work. Zheng Chuankun and Huang Qingji believed that the unnegligible political authority, the ability to detect key elements of an issue, and teams with large numbers of professionals had all contributed to the outstanding effects by the Central Leading Group for Inspection Work [7]. Li Zewei began his analysis from the work details of the Central Leading Group for Inspection Work and concluded that details such as there shall be no cameras close to the suggestion boxes, the parties in a conversation shall not be required to sign on the conversation records, and taking accounting professionals for accounts checking have greatly promoted the anti-corruption effectiveness of the Central Leading Group for Inspection Work [8]. Through the analysis of the characteristics of the inspection work by the Central Leading Group for Inspection Work, Liu Shaohua held that "the appointment of a different group leader each time for a different task" and "the Three Changeables (namely, the group leaders for the inspection groups are changeable; the inspected objectives (local governments and enterprises) are changeable; the relationship between the inspection groups and the inspected objectives are changeable)" had increased the uncertainty of the inspections, thus effectively prevented the local governments or enterprises gaining benefits from good relations with the inspection officials [9]. Wang Yangwen believed that problems such as the less-optimized touring inspector structures, the lack of democratic consciousness from the inspected objectives, the unclearly-defined subject matter for inspections and supervision, and a lack of external supervision for the touring inspection groups existed in the execution of the touring inspection system [10]. Zhu Xiqun and Hu Xiaojun pointed out that no anti-corruption law had ever been published in China, and the relevant existing laws and regulations messed up together or had some overlapping, or even contradicted with each other. Therefore, China lacks a sound and comprehensive system in this respect. Until now, there is no independent anti-corruption organ in China, thus an unsystematic situation arises, to be specific, though the ruling party, the government organizations and the judicial department fulfill their own responsibilities, the anti-corruption work is in essence organized and coordinated by the ruling Party's discipline inspection organs [3]. Ren Jianmin and Lin Wengen held that the top three factors that influenced the effectiveness of the touring inspection system include the authority's motives, the agent's motives and capacity and the asymmetric information in any particular supervision [11].

To sum up, the previous scholars had studied Ming Dynasty's Censorial Inspectors and the current Central Leading Group for Inspection Work quite well. Nevertheless, there was a lack of deep discussions and study on the anti-corruption mechanisms of them. What's more, why did Ming Dynasty's almost perfect system not really help the dynasty survive long? On the contrary, it even quickened the collapse of the late Ming. How could this happen? The disabled evolutionary mechanism of this anti-corruption system aroused little academic attention, either. From a long-term perspective, the effectiveness of the Central Leading Group for Inspection Work will present a trend of progressive marginal benefit decrease, and its way-out has not been touched by current studies. 
Besides, the Touring Censorial Inspector ever functioned quite resembles contemporary China's Central Leading Group for Inspection Work in organizational structure and mode of operation. In other words, both are powerful anti-corruption weapons of the state. Although studying the Censorial Inspector can be a generous help for the Group, these two are rarely correlated together in previous studies across the present academia.

\section{Research Methods and Data Acquisition}

\subsection{Literature Review}

By reading historical books such as The History of Ming Dynasty and the Constitution Outline, and Provisions of the Chinese Communist Party concerning On-site Inspection and other relevant literature about each round of touring inspection by the Central Leading Group for Inspection Work for this study, the writer makes an analysis of the entire touring inspection processes adopted by Ming Dynasty's Censorial Inspectors and the Central Leading Group for Inspection Work and summarizes their anti-corruption mechanisms. It is found that the unique mechanism for official selection and supervision, touring regulation, function exercise and returning examination in the Ming Dynasty's Censorial Inspector system had played a significant role in its anti-corruption work. But it is also found out through case analysis in this system that in the Early and Middle Ming's Censorial Inspectors often had better performance than those in the Late Ming Dynasty. And the current Central Leading Group for Inspection Work also possesses a touring inspection system that is composed of pre-inspection preparations, evidence collection in inspections, and documents submission after inspections. Through analysis of the data relating to those corrupted officials who have been removed from office as well as inspection group leaders, it is unveiled that the Central Leading Group for Inspection Work is growing ever stronger against the anti-corruption background, and its political authority, staffing and inspected objectives are all special and characterized with the features of times, which becomes a significant factor influencing its effectiveness, while also makes its future development unpredictable.

\subsection{Comparative Studies}

To explore the successiveness and innovations in the aspect of anti-corruption mechanism between the Ming Dynasty's Censorial Inspectors and the Central Leading Group for Inspection Work, comparative studies are adopted for furthering this research. The Central Leading Group for Inspection Work and the Ming Dynasty Censorial Inspectors are considered as objectives for comparison and the series of anti-corruption processes as the comparison content. In addition, indicators are designed based on the internal logic of the anti-corruption mechanisms for the purpose of comparison. This study aims to tap into the correlation between the mechanisms and provide basis for studies on the effectiveness of anti-corruption. It is found through comparison that, from the perspective of the operational mechanisms, there is a huge similarity existing between the Central Leading Group for Inspection Work and the Ming Dynasty's Censorial Inspectors, the essence of both mechanisms is concerned with the dispatching of touring inspectors by the central government to supervise the local government to ensure the state's political cleanness. The two mechanisms are methods for anti-corruption and share a great deal of similarities in anti-corruption practices, both being reflections of a kind of authorization-agency mechanism and possessing the characteristics of general authorization-agency mechanism. That is why it cannot be spared from the asymmetric information problem inherent in the authorization-agency mechanism. Different political systems come as results of different times, and different state dominant powers serve different interest groups. Through comparisons, it is found that the most remarkable difference between the Central Leading Group for Inspection Work and the Ming Dynasty's Censorial Inspectors is ascribed to the historical background in which they exist. Ming dynasty Built by Zhu Yuanzhang was the peak in the development of the feudal society. The political measures formulated and promulgated by the emperor must become the tools to rule people. The Ming Dynasty's Censorial Inspectors was no exception. It seems to have the certain independent, but it is always serving the emperor actually. Since the founding of new China in 1949, the Communist Party of China always adheres to serve the people heart and soul. As the main method of anti-corruption, the Central Leading Group for Inspection Work is also serve the people for our for our country's political correctness and officials clean. The essential differences between these two mechanisms come as a result of the different times, which particular attention shall be paid to in our current studies and also form an important breakthrough for improving the anti-corruption effectiveness by the Party. 


\subsection{Macro-Historical View}

By "macro-historical view", it is meant to interpret the history with a macro perspective and make certain predictions to the future social trends through analysis of the internal logic embodied in the past events and comparisons between what is happening now and what may happen in the future, and a long-term and comparative mentality shall be adopted for detecting problems. In this study, the Ming Dynasty's Censorial Inspector system and the mechanism behind the Central Leading Group for Inspection Work are comparatively studied from a macro-historical view to explore the similarities between these two's internal logic and to make reasonable predictions on the future of the Central Leading Group for Inspection Work. Based on a clarified understanding of these two mechanisms for anti-corruption, the writer finds that a remarkable similarity between the internal logic of both systems - the authorization-agency pattern of anti-corruption. In other words, both systems are manifestations of the authorization-agency pattern in different times. Therefore, the writer has, from the perspective of a micro-historical view, made reasonable predictions on the Central Leading Group for Inspection Work's future development and put forward suggestions for references on the basis of historical development in the Ming Dynasty's Censorial Inspector system.

\section{Comparative Studies and Relevant Discussions}

\subsection{Effectiveness of Anti-Corruption}

Effectiveness typically refers to how much and how well the planned activities are finished, namely, an analysis, based on a large quantity of sample data, as to how well the targets are accomplished after an event has been completed. However, some scholars have declared, "The effectiveness of anti-corruption system lies in the applicability of relevant rules and regulations within the system, in whether they are in compliance with the real situations and their operability. Whether the targets of a mechanism can be realized is decided by the reality and environment in which the system exists; if the established system is not practical, it is hard to have an effective implementation. The most optimal system shall be the most applicable. Many seemingly good systems will not produce actual effects against corruption if they are not practical, applicable or operable [12].” It can be seen that the anti-corruption effectiveness here attaches more importance to the reasonability, compliance to reality and operability of the system design itself, which is referred to as effectiveness in general sense by the writer.

In this study, the writer takes a macro-historical view for the comparative studies of the Ming Dynasty's Censorial Inspectors and the Central Leading Group for Inspection Work and finds that a significant similarity exists between the two mechanisms and the core pattern of which is the authorization-agency mechanism. As a result, the effectiveness here is not merely an analysis on the anti-corruption effectiveness of the Ming Dynasty's Censorial Inspectors and the Central Leading Group for Inspection Work; instead, it is to explore the nature and analyze the anti-corruption effectiveness from the perspective of the authorization-agency mechanism. Therefore, the effectiveness referred to in this study is more in compliance with "the effectiveness in general sense".

\subsection{Comparison of the Anti-Corruption Mechanisms between the Central Leading Group for Inspection Work and the Ming Dynasty's Touring Censorial Inspectors}

\subsubsection{Comparison of the Anti-Corruption Mechanisms}

The Ming Dynasty's Touring Censorial Inspectors and the Central Leading Group for Inspection Work, as the main bodies for similar duties with similar working methods in different times, are both related and of remarkable differences. Based on the indicator system established in the preceding section, the writer makes the following comparisons:

Pre-Touring Inspection. Both the Ming Dynasty’s Touring Censorial Inspectors and the Central Leading Group for Inspection Work need to be manned with special staff and prepared for relevant responsibilities and duties. The Touring Censorial Inspectors were selected through a set of rigorous system in the Ming Dynasty. Constitution Outline specified that each Censorial Inspector must be selected from "those righteous, sophisticated and honest persons with extensive experience. No newly presented scholar shall be appointed such title [3]. Instead, the Central Leading Group for Inspection Work is composed of the group leader, the deputy group leader and group members. Leaders at the ministerial level (and some at the vice-ministerial level) who have just left their posts at the CCDI or the Organization Department of the Central Committee of the CPC and have not 
yet gone through the retirement procedures will act as the group leaders. The wide range of duties involved is the most significant characteristics of the responsibilities of Ming Dynasty's Touring Censorial Inspectors, among which anti-corruption is just an important part of it. According to the Constitution Outline, the duties of the Touring Censorial Inspectors are mainly concerned with impeaching officials, checking files, hearing criminal cases, and checking various political affairs. As time passed by, the scope of their duties had been expanded [13]. However, different from the Touring Censorial Inspector system, the Central Leading Group for Inspection Work as a means to enhance inner-party supervision plays its supervising role in a top-down manner; and since the 18th CPC National Congress, the Central Leading Group for Inspection Work has cracked down hard on corruption, with anti-corruption becoming the focus of its duties.

Inspection in Process. The touring inspection periods for both the Ming Dynasty's Censorial Inspectors and the Central Leading Group for Inspection Work are specified. Though with a fixed touring period, there was still some flexibility in it for Ming's inspectors, whose inspection period might be prolonged if wars happened in the locality or the inspector was respected and well-received by the local residents during the inspection. But the Central Leading Group for Inspection Work was strictly restricted with respect to its touring inspection period, which generally lasted two months. As “informers" to the Emperor, Ming's inspectors toured the Emperor's jurisdiction and their relationship with the local administrative officials experienced two different stages. In the early and middle Ming Dynasty, the Censorial Inspectors and the local administrative officials gave support to and supervised each other; however, in the same period there were also many rules and regulations setting restrictions on the relationship between them in a bid to ensuring their independence from each other, such as "ban on the welcoming and seeing-off of Censorial Inspectors”, etc. [13]. Nevertheless, the deteriorating bureaucracy in the Late Ming Dynasty put the inspectors far above the local officials in power, turning the inspectors to be real controllers for local affairs. Different from the inspection system in the Ming Dynasty, the Central Leading Group for Inspection Work remains completely independent from the local administrative systems. As for external supervision, Ming's rules also specified that a touring inspector neglecting his duty or committing corruption should be treated as being triply guilty [13]. Besides, Ming Dynasty broke new ground in establishing the system of mutual impeachment between Touring Censorial Inspectors. However, though the Provisions of the Chinese Communist Party Regarding On-site Inspection has put forward clear requirements concerning the duties and responsibilities for the inspection groups, it lacks some rigid speculations on such duties as well as an explicit and detailed responsibility mechanism that applies and converts the touring inspection results.

Post-Inspection. Each Censorial Inspector's entire touring shall end with returning inspection or examination. As the Constitution Outline stipulated, "about affairs such as any inspector' separate outings, his inquiry of some matters and hearing of cases, the Censorate shall submit the list of items to the Emperor for any imperial edict each time; and when inspector comes back to the capital, he shall not report to the Censorate, but directly to the Emperor for double approval.” [13]. It meant that the inspector, though a member of the Censorate in name, was directly accountable to the Emperor. So, such inspector shall report the result of his touring to the Emperor directly. After completing its inspection, the Central Leading Group for Inspection Work will report to the Central Inspection Work Leading Group and give feedbacks regarding the problems found in the inspected areas and enterprises and put forward relevant suggestions to rectify and reform. According to the principles concerning leaders' management authorities, centralized management by specified departments, and each performing its own functions, the decisions made by the leading group shall be handed over to relevant departments of CCDI and the Organization Department of the Central Committee of the CPC or to relevant functional departments of the central government for settlement and timely supervision.

\subsubsection{Failure of Authorization-Agency Mechanism}

As information exchange was very limited in ancient times, each inspector as the Emperor's agent often toured for several months, which made him hard to feed back the information to the Emperor in time. So, any problem involving corruption would not be tackled promptly and this naturally minimized the efficiency, leading to a gradual malfunction of the authorization-agency relation between the Emperor and the inspector. In contrast, as the agency of the Central Inspection Work Leading Group, the Central Leading Group for Inspection Work performs on its behalf the touring inspection throughout China and on every state-owned enterprise for their construction of the Party conduct and of a clean and honest government and report the findings to the Central Inspection Work Leading Group at the end of the inspection period. In other words, the Central Inspection Work Leading Group as the initial authority assigns its Right of Picket to the Central Leading Group for Inspection 
Work. In nature, both the Central Leading Group for Inspection Work and Ming Dynasty’s Touring Censorial Inspectors are manifestations of the authorization-agency mechanism, which in modern economics is regarded as a type of contract, under which the authority assigns some of its decision-making rights to the agents who perform various operations and management activities in the name of the authority.

If the authority wants to fully understand and grasp the real information from the agents, he needs to pay the expenses for information collection and supervision, which are very costly and the marginal cost of which is higher than its marginal benefits. Therefore, the information between the authority and the agents is asymmetric. If the authorization-agency relationship is seen as a kind of contract relationship, then the asymmetric information exists both before and after the contract is concluded, bringing adverse selection and moral rent-seeking into being. For adverse selection, it is mainly involved with rent-seeking by the subordinates to their superiors, for instance, in the late Ming, the Censorial Inspectors even had more power than the local officials; and currently the leading groups as well as the group leaders not only abuse their power, conduct inaction, but also require no rectification and reforming actions from the inspected units and enterprises, and certain leaders from the Central Inspection Work Leading Group, including some leaders from the CCDI and the Organization Department of the Central Committee of the CPC, ignore the problems found out by the leading groups. While moral rentseeking refers to the fact that after a contract is concluded, due to the asymmetric information, one party of the contract inflicts damages to the other through conducting beneficial to itself and undetectable by the other. Because the information between the authority and the agent is asymmetric, the benefits from corruption by a Censorial Inspector himself was larger than the losses he might get from punishment, thus the agents were encouraged to take bribes and often did so through either the front-gate or backdoor of official bureau. However, the Central Leading Group for Inspection Work only functions to supervise and urge the rectification and reforming by the inspected units and enterprises during the later stages in the entire process, for the cases found shall be transferred to the Political Bureau of the Central Committee of the CPC, People's Court, and People's Procuratorate and other relevant departments via complex procedures. If the benefits from rent-seeking at each process is higher than that from reflecting the truth, relevant clues may get lost and corruption may transfer to some hidden forms.

\subsection{Drawing Lessons and Making Reflections}

The way in which both the Ming Dynasty's Touring Censorial Inspectors and the Central Leading Group for Inspection Work conduct their touring inspection for anti-corruption shares the same risk from the authorization-agency mechanism, which is inherent in the designs of both systems and acts as a hidden threat deeply rooted in both inspection mechanisms. The authorization-agency mechanism itself is subject to asymmetric information, leading to rent-seeking by relevant officials, which leads further to the nearly ineffectiveness of the anti-corruption mechanism. However, such authorization-agency mechanism for anti-corruption can only be accounted as the internal factor influencing the effectiveness of anti-corruption by both the Ming Dynasty's Touring Censorial Inspectors and the Central Leading Group for Inspection Work. Since different times are situated in different backgrounds, with different levels of information technologies, and what is more, different ruling teams on behalf of different interest groups, the external background will exert a significant influence on the anti-corruption mechanism in an authorization-agency relationship. The influence may sometimes even overshadow the problems within the anti-corruption mechanism itself.

It has been proved by history that the anti-corruption by the Ming Dynasty's Touring Censorial Inspectors were not effective. Apart from the problems of the authorization-agency mechanism in the Touring Inspection itself, we have to consider the influence from the external environment surrounding Ming — a traditional feudal dynasty. All the political measures in a feudal dynasty were with a sole purpose to safeguard the feudal regime and enhance the Emperor's sole privileges. Though the Censorial Inspectors were an important means against corruption, they were essentially a tool for the Emperor to rule his courtiers and plebs and without independence in a real sense. Eventually, it is hard for them to accomplish anti-corruption. Additionally, the almost collapsed traditional binding mechanism of Confucianism in the Ming Dynasty signifies the failure of an internal binding system on the officials. To make it worse, there was a short of external binding system to support it. Consequently, such defects were difficult to be compensated for. In contrast, the Central Leading Group for Inspection Work has made remarkable accomplishments regarding anti-corruption since the central government is now centering on the corruption issue and stepping up its efforts against corruption. But the Central Leading Group 
for Inspection Work is likewise an anti-corruption mechanism of authorization agency, therefore, there is still a need to mitigate the series of issues that may arise from such mechanism. As a result, the Central Leading Group for Inspection Work needs to take the internal and external factors into consideration and adopt comprehensive methods to ensure that the touring inspection will remain as what it is now and become an effective means against corruption. With these in mind, the writer reflects on the following issues:

\subsubsection{Stepping up Effort to Develop the Central Leading Group for Inspection Work's Anti-Corruption Function}

Before the 18th CPC National Congress, the Central Leading Group for Inspection Work, as an inner-Party touring inspection system, mainly served to keep the CPC clean, upright and advanced in nature and was short of a centralized function at its early stage. Nevertheless, with its working focus gradually shifting to anti-corruption, the Central Leading Group for Inspection Work has become increasingly effective in this respect. Therefore, stepping up efforts to develop its anti-corruption function and ensuring the powerful advances in this work is not only the direction that the Central Leading Group for Inspection Work shall strive for at present and in the future, and also an efficient way for it to have a continuous optimization for its anti-corruption function.

\subsubsection{Establishing an Effective Information Exchange Mechanism for Anti-Corruption}

The continuous development of IT technology makes it possible for long-distance, real-time communication, which also provides possibilities to mitigate the problem of asymmetric information in the authorization-agency mechanism. So the establishment of an effective information exchange system for anti-corruption is currently an important means to enhance the Central Leading Group for Inspection Work's effectiveness in anti-corruption. Moreover, we can take advantage of the latest Internet development, such as introducing government affairs microblog into the Central Leading Group for Inspection Work, to enable the public to follow the anti-corruption processes in a convenient manner. Besides, information network also needs to be established within the Central Leading Group for Inspection Work for the promotion of convenient information transmission.

\subsubsection{Strengthening and Improving the Central Leading Group for Inspection Work's Legal System Construction}

At present, the Central Leading Group for Inspection Work can only fight against corruption according to the Provisions of the Chinese Communist Party Regarding On-site Inspection which was issued in 2009 and modified in 2015. What is more, the relevant laws concerning anti-corruption in China are scattered in a variety of legal provisions without a specified organ to lay down such rules and regulations. There is a short of a special anti-corruption law. As a result, this leads to a lack of detailed instructions to the Central Leading Group for Inspection Work in its specific anti-corruption operations and a lack of a corresponding set of well-established and binding supervising measures. Therefore, the effectiveness of anti-corruption by the Central Leading Group for Inspection Work is diminished to a large extent and hard to be matched with a sound anti-corruption legal system. So strengthening and improving the Central Leading Group for Inspection Work's legal system construction and effectively dealing with its inspection findings will be helpful for the Central Leading Group for Inspection Work to make new heights in its anti-corruption work.

\section{Conclusions}

Xia-Shang-Zhou Period had sparked the primeval feudal inspection system, which then struck root in Qin and Han, prospered between Sui, Tang and Song, and finally reached its pinnacle in Ming and Qing. But all of these can be boiled down to the authorization-agency mode in which the central governments dispatch officials to different localities for anti-corruption inspection, and the Central Leading Group for Inspection Work also inherits this traditional ancient touring inspection system. However, the authorization-agency mechanism itself is bothered with problems to be solved. The thousand-year history tells us that anti-corruption via touring inspect may be effective in a short term, but from a long-term perspective such method has not been completely effective in eradicating corruption in any dynasty in our history. Therefore, it can be speculated that the Central Leading Group for Inspection Work must also embark on a rough road for anti-corruption. If it hopes to maintain the anti-corruption efficiency as now, the shortcomings inherent in the authorization-agency mechanism have to be overcome, the anti-corruption mechanism needs to be redesigned and optimized, and lessons have to 
be drawn from the past for references, otherwise the Central Leading Group for Inspection Work would eventually fall into the same anti-corruption dilemma as the ancient Touring Censorial Inspectors do and its anticorruption effectiveness would be on a marginal decrease.

In the face of complex anti-corruption issues, the Central Leading Group for Inspection Work serves only as one of the many tools against corruption. Therefore, it is unreliable to depend solely on this tool that may be troubled with potential problems itself, and it is also hard for China to put all its hopes for the future of anticorruption on the Central Leading Group for Inspection Work. For now, to tackle the anti-corruption issues, a comprehensive analysis is needed to understand the characteristics of corruption in China so as to take a combination of proper measures. Based on China's current anti-corruption situation, the writer believes that the fights against corruption can be safeguarded with the establishment of external systems, including strengthening the anti-corruption legal system construction and integrating the anti-corruption legal system construction into the framework of law-based governance. In the future, emphasis shall be put on the re-construction of the inherent system while the external system is in function, that is, to set a standard of "incorruption" in people's mind. Only when both the inherent and external systems are playing their roles may corruption be finally eliminated.

\section{References}

[1] Jiang, D.H. (2014) On the Perfection of China’s Anti-Corruption Political Ethics. Journal of Tongji University (Social Science Section), 25, 92-101.

[2] Yu, X.A. (1992) A Study of Ming Dynasty’s Touring Censorial Inspection System. Journal of Chinese Historical Studies, 1, 74-84

[3] Zhu, X.Q. and Hu, X.J. (2014) The Demonstration Effect and Institutionalization of the Anti-Corruption by the Central Leading Group for Inspection Work. Leaders’ Companion, 2, 5-6.

[4] Cai, M.L. (2014) Rise and Fall of Touring Censorial Inspector System in Ming Dynasty. China Discipline Inspection Daily, 20, 62-63.

[5] Liang, E.M. (2007) Discussion on the Supervising Power of Touring Censorial Inspector in Ming Dynasty. History Teaching (Higher Education Edition), 8, 16-20.

[6] Ai, Y.M. (2013) Alienation and Drawbacks of “Touring Inspection” System in Ming and Qing. Policy Research \& Exploration (Published in the Second Half of Each Month), 7, 74-76.

[7] Zheng, C.K. and Huang, Q.J. (2009) Perfecting Inner-Party Supervision and Improving the Touring Inspection System. CASS Journal of Political Science, 5, 68-73.

[8] Li, Z.W. (2015) Unveiling the Inspection Groups’ Work Details. Leaders’ Companion, 1, 33-34.

[9] Liu, S.H. (2015) Real Problems Reflected in the Sharp Words by the Central Leading Group for Inspection Work. People's Daily (Overseas Edition), 2015-02-14 (002).

[10] Wang, Y.W. (2010) Dilemma for the Execution of the Touring Inspection System and the Practical Way-Out. Forward Position, 10, 7-9.

[11] Ren, J.M. and Lin, W.G. (2009) Study on the Touring Inspection System and Its Sustainable Development. Journal of Guangzhou University, 10, 14-18.

[12] Huang, Y. and Zhao, R. (2006) Reflections on Improving the System's Effectiveness on Anti-Corruption. Journal of Fujian Provincial Committee Party School of CPC, 4, 19-21.

[13] Zhang, L.J. (1995) Huangmingzhishu. Shanghai Classics Publishing House, Shanghai. 


\section{Submit or recommend next manuscript to SCIRP and we will provide best service for you:}

Accepting pre-submission inquiries through Email, Facebook, LinkedIn, Twitter, etc.

A wide selection of journals (inclusive of 9 subjects, more than 200 journals)

Providing 24-hour high-quality service

User-friendly online submission system

Fair and swift peer-review system

Efficient typesetting and proofreading procedure

Display of the result of downloads and visits, as well as the number of cited articles

Maximum dissemination of your research work

Submit your manuscript at: http://papersubmission.scirp.org/ 